\title{
Response of bacteria to simulated upwelling phytoplankton blooms
}

\author{
Michael S. Wetz*, Patricia A. Wheeler \\ College of Oceanic and Atmospheric Sciences, 104 Ocean Administration Building, Oregon State University, \\ Corvallis, Oregon 97330, USA
}

\begin{abstract}
Until recently, studies of the fate of primary production in coastal upwelling systems have focused mainly on export through sinking of particulate organic matter (POM). In week-long deck incubations conducted during the upwelling season off Oregon, a large accumulation of carbonrich $(\mathrm{C}: \mathrm{N} \geq 16$ ) dissolved organic matter (DOM) occurred following nitrate depletion by diatom blooms. The response of bacterioplankton to the DOM release in the incubations was observed using flow cytometric analysis of abundances of bacteria with high nucleic acid (HNA) and low nucleic acid (LNA) content. Relatively small increases in the abundance of HNA bacteria were observed in nitrate-replete conditions $\left(<1.0 \times 10^{6} \mathrm{cells} \mathrm{m}^{-1}\right)$. Coincident with nitrate depletion and accumulation of the DOM, abundances and growth rates of HNA bacteria increased rapidly while little response was observed from LNA bacteria. Although growth rates and abundances of HNA cells increased markedly, a net decrease in dissolved organic carbon (DOC) was observed in only 1 incubation. Within approximately $1 \mathrm{~d}$ of nitrate going to depletion, HNA bacterial abundances peaked and then decreased rapidly, possibly due to flagellate grazing or viral lysing. These results indicate that on the timescale of upwelling/relaxation events, which generally last 7 to $10 \mathrm{~d}$, environmental controls on bacterial populations may prevent complete degradation of phytoplankton-derived DOM, thus allowing some of this material to be exported from the system through physical processes following termination of the upwelling event.
\end{abstract}

KEY WORDS: Dissolved organic matter · Upwelling · Bacteria · Phytoplankton · Flow cytometry · Flagellates · Nitrogen

\section{INTRODUCTION}

Recent studies have shown that autochthonously produced DOM is an important component of $\mathrm{C}$ and $\mathrm{N}$ budgets in upwelling systems (Álvarez-Salgado et al. 2001, Hill \& Wheeler 2002). However, the fate of phytoplankton-derived DOM in coastal upwelling systems is largely unknown due to the chemical complexity of the pool, which affects its biological availability and influences export pathways. Some DOM produced by phytoplankton is rapidly (hours to days) respired (reviewed by Carlson 2002), and DOM that is assimilated by microbial communities can largely be ignored in export estimates due to the fact that the microbial food web contributes little to the sinking flux of POM
(Eppley \& Peterson 1979). The DOM that is not affected by microbial activity can then potentially be exported from the system through physical mechanisms such as vertical mixing or horizontal advection (Carlson et al. 1994, Peltzer \& Hayward 1996) or by incorporation of the DOM into rapidly sinking aggregates (i.e. transparent exopolymer particles, TEP) through abiotic processes (Passow 2000).

Seasonal upwelling off Oregon occurs from roughly May through September and often results in the development of large (>10 $\mu \mathrm{g}$ chlorophyll $\mathrm{al}^{-1}$ ) phytoplankton blooms and accumulation of POM and DOM in surface water that is in excess of deep water concentrations (Hill \& Wheeler 2002). However, upwelling does not occur as 1 continuous process throughout the season, but rather 
as multiple 'events'. Upwelling events are initiated following periods of northerly winds, which can prevail for several days to roughly $1 \mathrm{wk}$ (reviewed by Smith 1995) and are often followed by several more days of relaxed winds. Stratification of the water column is frequently observed during the periods of subsequent wind relaxation, and this stratification can provide the necessary conditions for rapid phytoplankton growth, i.e. a shallow mixed layer and high nutrient concentrations. Upwelling/relaxation events cease when winds reverse direction, becoming southerly, downwelling-favorable, which can also break down stratification of surface waters (Smith 1995).

Coastal upwelling phytoplankton blooms typically peak in $<1$ wk from initiation, and, off Oregon, blooms are frequently terminated by nitrate depletion (Corwith \& Wheeler 2002, Wetz \& Wheeler 2003). Several studies have demonstrated release of copious amounts of DOM following nutrient limitation of blooms (Goldman et al. 1992, Norrman et al. 1995, Smith et al. 1998, Sondergaard et al. 2000, Wetz \& Wheeler 2003). Because upwelling/relaxation events may last up to $10 \mathrm{~d}$ or so, the phytoplankton-derived DOM is then potentially affected by bacterial activity. There is considerable evidence that a large fraction of bacteria in situ is metabolically inactive (e.g. Zweifel \& Hagstöm 1995, Sherr et al. 1999a,b) and that only certain groups of bacteria respond to substrate additions with enhanced metabolic activity and growth. Using nucleic acid stains and flow cytometry, Li et al. (1995) were able to discriminate 2 groups of bacteria, 1 with cells having a HNA content and 1 with cells having a LNA content. Subsequent studies have shown that HNA bacteria generally correspond to the metabolically active fraction of marine bacteria, while LNA bacteria are thought to be dead or inactive cells (Gasol et al. 1999, Gasol \& del Giorgio 2000, but see Zubkov et al. 2001 for a case where LNA bacteria were not dead or inactive). A field study in shelf waters off Oregon (K. Longnecker et al. unpubl. data) and studies in a variety of other systems have demonstrated that HNA cells account for most of the bacterial production and have higher cell-specific activities than LNA cells (Li et al. 1995, Lebaron et al. 2001, Vaqué et al. 2001, Servais et al. 2003).

The goal of this work was to examine the response of the 2 groups of bacteria, HNA and LNA, to simulated upwelling phytoplankton blooms. Given that DOM in newly upwelled water is enriched in carbon relative to nitrogen and is believed to be somewhat refractory (Hill \& Wheeler 2002), we hypothesized that bacterial growth would occur in response to development of phytoplankton blooms and DOM released by those blooms. We also evaluated the role of nitrogen limitation and grazing by heterotrophic flagellates as con- trols on bacterial growth. Because the incubations lasted 7 to $8 \mathrm{~d}$, which is on the timescale of an upwelling/relaxation event, we interpret the results in terms of the fate of phytoplankton-derived DOM in the Oregon upwelling system.

\section{MATERIALS AND METHODS}

A detailed description of the experimental design can be found in Wetz \& Wheeler (2003). Briefly, experiments were run over a $3 \mathrm{wk}$ period in August 2001 during the peak of the upwelling season. Water samples for 2 incubations (Nos. 1 and 2) were collected from mid-shelf sites off northern Oregon $\left(45.00^{\circ} \mathrm{N}\right.$, $124.02^{\circ} \mathrm{W}$ ) and water samples for the other 2 incubations (Nos. 3 and 4) were collected from mid-shelf sites off central Oregon $\left(44.13^{\circ} \mathrm{N}, 124.28^{\circ} \mathrm{W}\right.$ and $44.06^{\circ} \mathrm{N}$, $124.33^{\circ} \mathrm{W}$ respectively). The sites differ in that the northern Oregon shelf is relatively narrow, while off central Oregon the shelf is broad and a bank exists near the outer shelf that allows for longer retention times of water inshore of the bank.

For each incubation, triplicate $20 \mathrm{l}$ high density polyethylene (HDPE) Cubitainers ${ }^{\mathrm{TM}}$ were filled with $1 \mathrm{l}$ of surface water inoculum and $19 \mathrm{l}$ of water from below the mixed layer (ca. 28 to $70 \mathrm{~m}$ ). Seawater was pumped directly into the Cubitainers ${ }^{\mathrm{TM}}$ from depth using a towed sled with a pump attached (Hales \& Takahashi 2002). Prior to being filled, Cubitainers ${ }^{\mathrm{TM}}$ were vigorously rinsed with $10 \% \mathrm{HCl}$ followed by multiple rinses with deionized water. Cubitainers ${ }^{\mathrm{TM}}$ were held in a deck incubator at in situ surface water temperatures averaging $13.5^{\circ} \mathrm{C}$. The incubator was covered with 1 layer of neutral-density mesh screen that reduced light intensities to ca. $50 \%$ of surface intensities. There were approximately $14 \mathrm{~h}$ of light and $10 \mathrm{~h}$ of darkness daily during the cruise, and daily integrated PAR values at the surface ranged from 15.0 to 52.0 mol quanta $\mathrm{m}^{-2} \mathrm{~d}^{-1}$ (mean $=31.6 \pm 12.0 \mathrm{~mol}$ quanta $\left.\mathrm{m}^{-2} \mathrm{~d}^{-1}\right)$. Moderate mixing of samples occurred due to the motion of the ship, and the Cubitainers ${ }^{\mathrm{TM}}$ were inverted manually once or twice daily. Cubitainers ${ }^{\mathrm{TM}}$ were sampled daily in the early morning (07:00 to 10:00 local time).

Biological analyses. Samples for chlorophyll a analysis were vacuum-filtered $(<200 \mathrm{~mm} \mathrm{Hg})$ onto GF/F filters and stored in glass Vacutainers ${ }^{\mathrm{TM}}$ at $-30^{\circ} \mathrm{C}$ until laboratory analysis. Chlorophyll a was extracted from the filters for $\geq 12 \mathrm{~h}$ in the dark at $-20^{\circ} \mathrm{C}$ using $95 \%$ methanol, and fluorescence was measured with a Turner 10-au fluorometer.

Flow cytometric analysis was done using a BectonDickinson FACSCalibur flow cytometer with a $15 \mathrm{~mW}$ laser at $488 \mathrm{~nm}$ following a protocol modified from Marie et al. (1997). Briefly, samples were preserved 
with freshly made $2 \%$ paraformaldehyde, quickfrozen in liquid nitrogen, and stored at $-80^{\circ} \mathrm{C}$ until flow cytometric analysis in the laboratory. For each sample, $250 \mu \mathrm{l}$ of $0.2 \mu \mathrm{m}$-filtered deionized water was pipetted into a cytometer tube, followed by $45 \mu \mathrm{l}$ of $0.2 \mu \mathrm{m}$ filtered potassium citrate. Next, $250 \mu \mathrm{l}$ of freshly thawed sample was pipetted into the cytometer tube, followed by $5 \mu \mathrm{l}$ of a 1:10 000 diluted nucleic acid stain, SYBR Green I (Molecular Probes). Finally, after brief vortexing and storage in the dark for ca. $10 \mathrm{~min}, 25 \mu \mathrm{l}$ of $1.0 \mu \mathrm{m}$ calibrated beads of known abundance were pipetted into the cytometer tube and the sample was gently vortexed again. Samples were analyzed at low flow rates (ca. 10 to $12 \mu \mathrm{min}^{-1}$ ), and bacteria were discriminated according to their side-scattering (related to cell size) and green fluorescence emission (measured at $530 \mathrm{~nm}$ and related to nucleic acid content) properties. Analyses were plotted on a logarithmic scale, and gates (windows) were drawn around heterotrophic bacteria cells on the cytogram to delimit them from cyanobacteria and prochlorophytes, based on orange fluorescence. Within the gates containing heterotrophic bacteria, gates were also drawn around HNA and LNA cells, as these showed up as distinct groups. When the coefficient of variation for the triplicate bacterial abundance measurements was $>15 \%$, a sample value was removed if it was greater than $1 \mathrm{SD}$ away from the mean of the triplicates; 8 HNA measurements and 9 LNA measurements out of 90 measurements total were excluded. The average coefficient of variation for all HNA replicates was $8.91 \pm$ $4.90 \%$, and for LNA replicates it was $9.13 \pm 4.45 \%$. Net growth rates of each bacterial group were calculated assuming exponential growth.

Samples for heterotrophic nanoflagellate abundance were collected in $250 \mathrm{ml}$ HDPE bottles predispensed with $150 \mu \mathrm{l}$ of alkaline Lugol's solution. Immediately after collection, $7.5 \mathrm{ml}$ of borate buffered formalin and $300 \mu \mathrm{l}$ of $3 \%$ sodium thiosulfate were added. After storage in the refrigerator for ca. $12 \mathrm{~h}$, a 10 to $50 \mathrm{ml}$ sample was concentrated to $2 \mathrm{ml}$ via vacuum filtration ( $<5 \mathrm{~mm} \mathrm{Hg}$ ) over a $0.8 \mu \mathrm{m}$ black membrane filter. Then, $50 \mu \mathrm{l}$ of DAPI was added to the last $2 \mathrm{ml}$ of sample, and it was allowed to stain for $7 \mathrm{~min}$ in the dark. Finally, the sample was filtered onto the black membrane filter on a slide. Heterotrophic nanoflagellates were counted at $400 \times$ magnification using a Zeiss epifluorescent microscope, and were distinguished from phototrophic nanoflagellates by alternating between UV and blue-light excitation. A minimum of 20 counting grids or 200 cells were counted for each sample.

Chemical analyses. Nutrient samples were collected in acid-washed $30 \mathrm{ml}$ HDPE bottles and immediately frozen at $-30^{\circ} \mathrm{C}$ until analysis. Samples were analyzed on a Technicon AA-II according to the standard wet chemical methods of Gordon et al. (1995). The detection limit for nitrate was $0.26 \pm 0.17 \mu^{2} \mathrm{~mol} \mathrm{l}^{-1}$. Total organic carbon (TOC) samples were collected in borosilicate vials with Teflon cap liners. Each vial contained approximately $5 \mathrm{ml}$ of seawater that was preserved with $50 \mu \mathrm{l}$ of $90 \%$ phosphoric acid. Samples were stored at room temperature until being processed 3 mo later. Samples were analyzed using the high temperature catalytic combustion method on a Shimadzu TOC-5000A analyzer. Particulate organic carbon (POC) and particulate organic nitrogen (PON) were determined from material collected on precombusted GF/F filters. Water samples were pre-filtered through a $202 \mu \mathrm{m}$ mesh screen to remove zooplankton. Then, 500 or $1000 \mathrm{ml}$ of the filtered water was vacuumfiltered ( $<200 \mathrm{~mm} \mathrm{Hg}$ ) onto precombusted GF/F filters. After filtration, samples were stored in glass Vacutainers ${ }^{\mathrm{TM}}$ and immediately frozen at $-30^{\circ} \mathrm{C}$ until laboratory analysis. Samples were processed within 2 mo of collection. Filters were fumed with concentrated $\mathrm{HCl}$ to remove inorganic carbon and dried, followed by analysis using a Control Equipment Corporation 440HA CHN elemental analyzer calibrated with acetanilide. Total nitrogen (TN) samples were collected in acidwashed $60 \mathrm{ml}$ HDPE bottles and immediately frozen at $-30^{\circ}$ until analysis in the laboratory. Organic nitrogen was converted to nitrate using a persulfate wet-oxidation method (Libby \& Wheeler 1997) and analyzed using a Technicon AA-II. DOC was determined by subtracting POC values from TOC values, and DON was determined by subtracting PON and dissolved inorganic nitrogen (DIN) from TN. The standard deviation for DOC was calculated by propagation of error using standard deviations for TOC and POC, and for DON by propagation of error using standard deviations for TN, DIN and PON (Bevington 1969). More detailed descriptions of all the chemical methods used can be found in Wetz \& Wheeler (2003).

\section{RESULTS}

\section{Phytoplankton bloom development and organic matter production}

Phytoplankton blooms developed in all 4 incubations and chlorophyll a peaked in 4 to $6 \mathrm{~d}$, with maximum chlorophyll a (chl a) concentrations ranging from 23 to $41 \mathrm{\mu g} \mathrm{chl} \mathrm{al}^{-1}$ (Fig. 1). In the first 3 incubations, blooms were composed primarily of the diatom Chaetoceros sp., while in the fourth incubation the bloom was composed primarily of the smaller diatom Leptocylindrus minimus. All the blooms terminated coincident with nitrate depletion (Fig. 1). Initial DOC and DON concentrations were low (48.7 to $54.5 \mu \mathrm{mol} \mathrm{l}^{-1} \mathrm{DOC}$ and 4.9 to $7.3 \mu \mathrm{mol}$ 


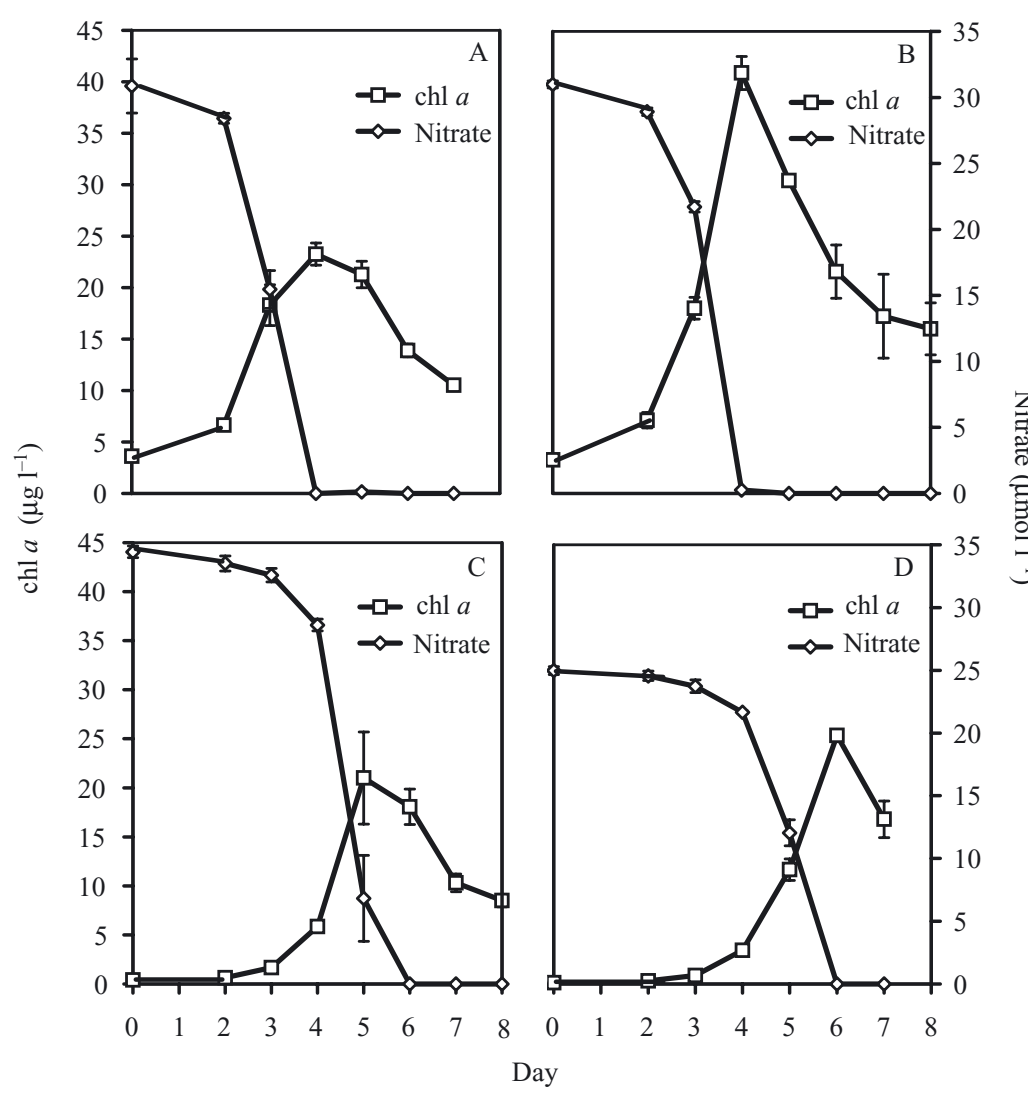

Fig. 1. Chlorophyll $a$ and nitrate in deck incubations. (A-D) Incubations 1 to 4 respectively. Error bars: \pm SD

$\left.\mathrm{I}^{-1} \mathrm{DON}\right)$, except in the first incubation where they were elevated (225 $\mu \mathrm{mol} \mathrm{l} \mathrm{l}^{-1}$ DOC and $17.8 \mu \mathrm{mol} \mathrm{l}^{-1}$ DON) (Fig. 2). A vertical profile conducted $1 \mathrm{~d}$ after the water for the first incubation was collected showed elevated DOC and DON concentrations throughout the water column (127 to $252 \mu \mathrm{mol} \mathrm{l}{ }^{-1}$ DOC and 19 to $24 \mu \mathrm{mol} \mathrm{l}^{-1}$ DON) (P. A. Wheeler unpubl. data). No DOM accumulated in nitrate replete conditions except in the second incubation where 14.0 to $26.4 \mu \mathrm{mol} \mathrm{l}^{-1} \mathrm{DOC}$ and 2.70 to $6.30 \mu \mathrm{mol} \mathrm{l}^{-1}$ DON accumulated (Fig. 2).

Immediately following nitrate depletion, large amounts of carbon-rich DOM (C:N $\geq 16)$ accumulated over a period of $1 \mathrm{~d}$ (Fig. 2). In blooms dominated by Chaetoceros sp., 109 to $161 \mu \mathrm{mol} \mathrm{l^{-1 }}$ DOC and 6.3 to $9.4 \mathrm{~mol} \mathrm{l}^{-1}$ DON accumulated, and in the Leptocylindrus minimus-dominated bloom, $41 \mu \mathrm{mol} \mathrm{l}^{-1} \mathrm{DOC}$ and $2.8 \mu \mathrm{mol} \mathrm{l}^{-1}$ DON accumulated. Approximately $42 \%$ of the initial accumulation of DOC and $80 \%$ of the initial accumulation of DON was drawn down the following day in the first incubation, but subsequently increased to near maximal values (Fig. 2A). In the other 3 incubations, DOC concentrations remained constant or increased following the initial accumulation (Fig. 2B-D). In the first and third incubations, the ini- tial DON build-up was transient, as 80 and $92 \%$ respectively were removed by the following day (Wetz \& Wheeler 2003).

\section{Bacterial abundance and DNA content}

During exponential growth of the phytoplankton, relatively little change in bacterial abundance occurred (Fig. 3). Small increases in the abundance of HNA bacteria were observed $\left(<1.0 \times 10^{6} \mathrm{cells} \mathrm{ml}^{-1}\right)$ (Fig. 3$)$, but their net growth rates were low (mean = $0.24 \pm 0.07 \mathrm{~d}^{-1}$ ) (Table 1). Abundances of LNA cells increased slightly during the development of the phytoplankton blooms, but the increases were $\leq 0.16 \times 10^{6}$ cells ml $^{-1}$ in all 4 incubations (Fig. 3). Net growth rates of LNA cells ranged from 0.08 to $0.20 \mathrm{~d}^{-1}$ (mean $=0.12 \pm 0.06 \mathrm{~d}^{-1}$ ) during that time (Table 1).

Immediately after nitrate was depleted and the phytoplankton blooms began to decline, bacterial abundances increased markedly (Fig. 3). This increase occurred concomitant with the DOM release from the phytoplankton blooms. Abundances of HNA cells increased 2- to 9-fold during the DOM build-up, with maximum abundances ranging from 3.67 to $12.3 \times 10^{6} \mathrm{cells} \mathrm{ml}^{-1}$ (Fig. 3). Net growth rates of HNA cells increased noticeably as well, ranging from 0.38 to $1.11 \mathrm{~d}^{-1}\left(\right.$ mean $\left.=0.81 \pm 0.32 \mathrm{~d}^{-1}\right)($ Table 1$)$. In contrast to the response by the HNA bacteria, abundances of LNA bacteria increased significantly ( $t$-test; $p<0.05$ ) in only 1 incubation during the period of DOM build-up (Fig. 3A). The net growth rate of LNA bacteria in that incubation was $0.46 \mathrm{~d}^{-1}$ (Table 1). In the other incubations, abundances of LNA bacteria remained constant (Fig. 3C,D) or decreased (Fig. 3B). Similarly, net growth rates of LNA cells in Incubations 3 and 4 were $0.06 \mathrm{~d}^{-1}$ and $0.05 \mathrm{~d}^{-1}$ respectively, and net growth rates in Incubation 2 were negative (Table 1). After several days of rapid growth, abundances of HNA bacteria in the first 3 incubations peaked and then decreased considerably over the remaining 1 to $2 \mathrm{~d}$ of the incubations (Fig. 3A-C). It is unclear whether the bacteria had reached maximum abundance in the fourth incubation, as that experiment was ended on Day 7.

\section{Heterotrophic nanoflagellate abundance}

All heterotrophic flagellates enumerated were smaller than $12 \mu \mathrm{m}$ in diameter. The contribution of larger mixotrophic dinoflagellates and naked flagel- 
lates could not be quantified, but autofluorescing cells of both groups were present. Abundances of heterotrophic nanoflagellates were low at the start of the incubations, ranging from 100 to 500 cells $\mathrm{ml}^{-1}$ (mean = $300 \pm 100$ ) (Table 2). Between the beginning of the incubations and the end of exponential growth of the phytoplankton, flagellate abundance increased by 2.5 to 7 -fold (Table 2). The largest absolute increases in flagellate abundance occurred following nitrate depletion, and maximum abundances ranged from 2970 to 13340 cells $\mathrm{ml}^{-1}$ (Table 2 ).

\section{DISCUSSION}

\section{Bacterial response to phytoplankton blooms}

During exponential growth of the phytoplankton, small increases in the abundance of HNA bacteria were observed, although DOM concentrations generally remained constant. The bacteria may have been using the background DOM, although no decrease in the concentration of the initial C-rich DOM (C:N $=7.5$ to 12.7 ) was observed. Thus, it is also possible that the bacteria were using DOM excreted either by the growing phytoplankton or from grazers. Diffusive loss of small amounts of DOM may be a common characteristic of phytoplankton physiology, even among presumably healthy cells (Bjørnsen 1988), and microzooplankton grazers are a known source of DOM (e.g. Strom et al. 1997). In a mesocosm phytoplankton bloom in the Benguela upwelling system, Painting et al. (1989) also observed that bacteria grew during development of the bloom, presumably in response to increased availability of labile DOM.

Coincident with nitrate depletion and the large accumulation of carbon-rich DOM $(\mathrm{C}: \mathrm{N} \geq 16)$, abundances and net growth rates of HNA bacteria increased rapidly. Net growth rates were slightly lower in the second incubation than in the others, possibly due to an earlier increase in heterotrophic flagellate abundance. In contrast to the increase in HNA bacterial abundance, little response was observed from the LNA bacteria. This is consistent with the results of $\mathrm{K}$. Longnecker et al. (unpubl. data), who found that in shelf waters off Oregon during the upwelling season, HNA bacteria usually had much higher cell-specific rates of leucine incorporation than LNA bacteria and accounted for a larger portion of total bacterial community ${ }^{3} \mathrm{H}$-leucine incorporation. Those authors are currently working to determine whether the HNA and LNA bacteria were phylogenetically distinct from one another.

Although net growth rates and abundances of HNA cells increased markedly in our incubations in response to the DOM release, a decrease in the phytoplanktonderived DOC was only observed in 1 incubation. In the first incubation, a net decrease of approximately $45 \mu_{\mathrm{mol} \mathrm{l}} \mathrm{l}^{-1}$ DOC and $5.3 \mu \mathrm{mol} \mathrm{l}^{-1}$ DON occurred as bacterial abundances peaked (Figs. 2A \& 3A). Assuming a cellular $\mathrm{C}$ and $\mathrm{N}$ content for the HNA bacteria of $30 \mathrm{fg} \mathrm{C}$ and $5.7 \mathrm{fg} \mathrm{N}$ (Fukuda et al. 1998) as well as a carbon growth yield of $27 \%$ (del Giorgio \& Cole 2000), we estimate that in this experiment bacterial uptake could account for all of the DOC usage and roughly $73 \%$ of DON usage. Although $30 \mathrm{fg} \mathrm{C}$ cell $^{-1}$ is relatively high, Fukuda et al. (1998) showed that coastal bacteria have higher $\mathrm{C}$ and $\mathrm{N}$ contents than open-ocean bacteria, and thus use of the canonical value of $20 \mathrm{fg} \mathrm{C}^{\mathrm{C}} \mathrm{cell}^{-1}$ would underestimate their biomass (Ducklow 2000). The lack of decrease in DOM concentrations in the other incubations, despite enhanced bacterial growth, could suggest that the transient bacterial response was stimulated by the relatively labile fraction of DOM (i.e. sugars, amino acids, soluble proteins) that was turned over rapidly

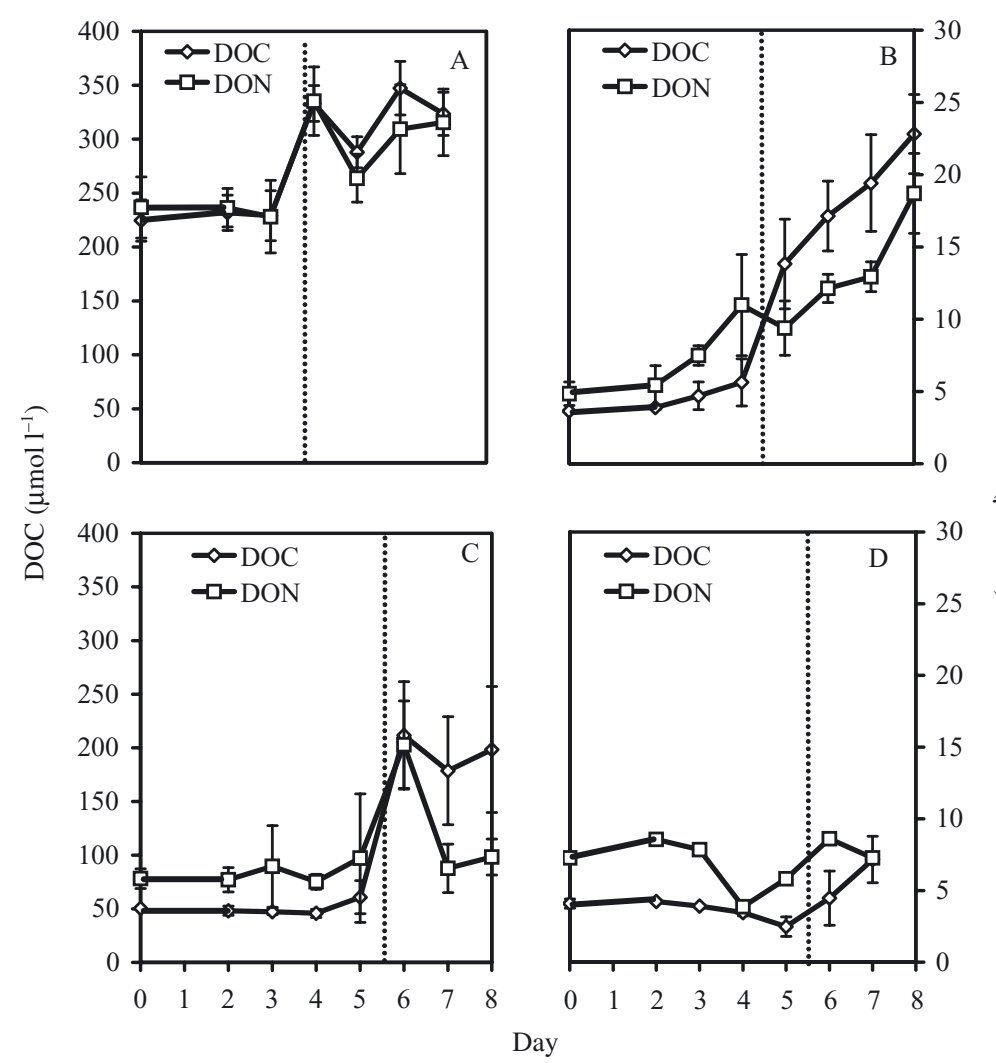

Fig. 2. Dissolved organic carbon and dissolved organic nitrogen in deck incubations. Dashed lines indicate time of nitrate depletion. (A-D) Incubations 1 to 4 respectively. Error bars: \pm SD 


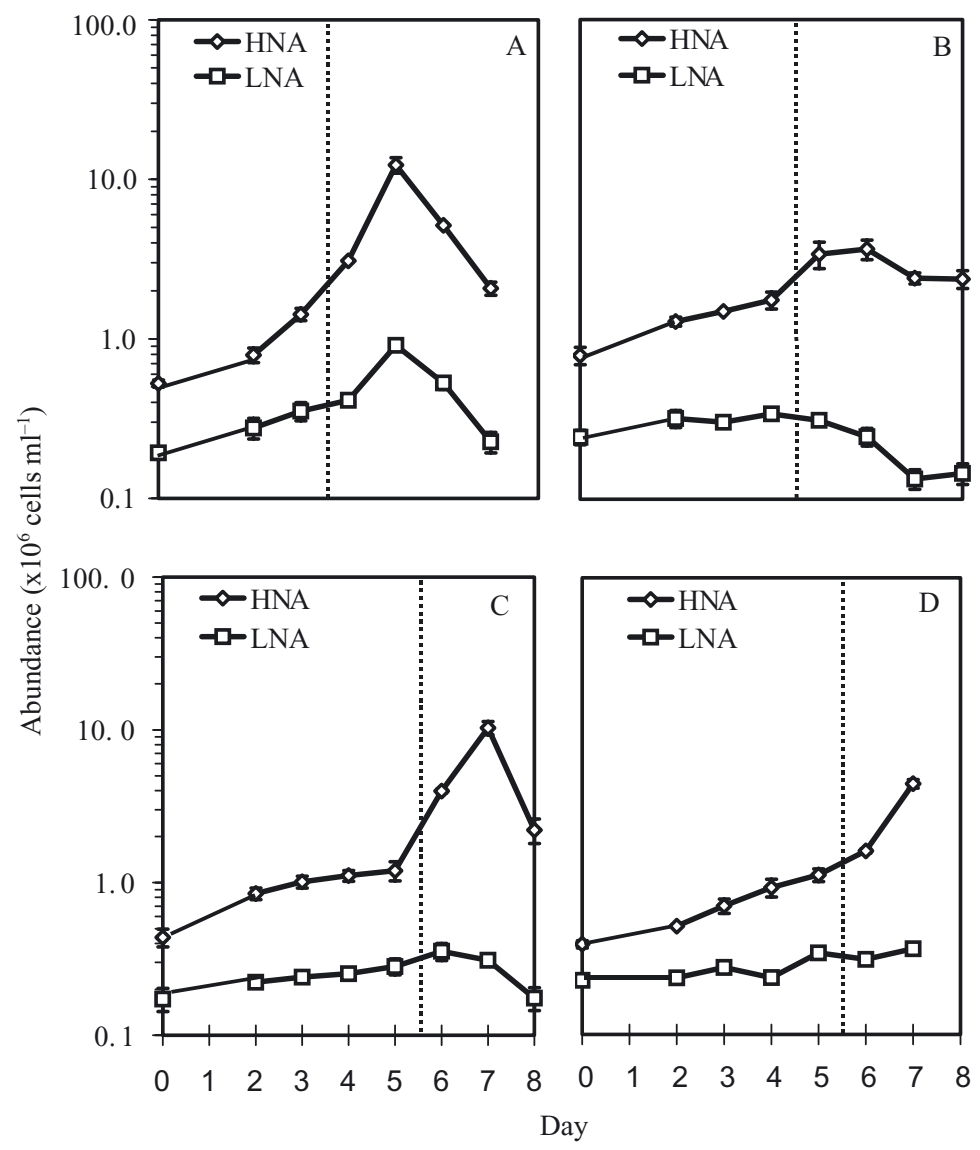

Fig. 3. Abundance of high nucleic acid (HNA) and low nucleic acid (LNA) bacteria in deck incubations $\left(\times 10^{6}\right.$ cells $\left.\mathrm{ml}^{-1}\right)$. Dashed lines indicate time of nitrate depletion. (A-D) Incubations 1 to 4 respectively. Error bars: \pm SD enough to be missed by our bulk DOM measurements (Chen \& Wangersky 1996). In mid-shelf waters off Oregon, bacterial activity was strongly related to chlorophyll a concentrations but not DOC, suggesting that the bacterial activity was stimulated by labile DOC released by phytoplankton or through food web interactions (Sherr et al. 2001). We would need to characterize the phytoplankton DOM on a finer level and also get estimates of turnover times of specific DOM pools in order to better elucidate which components of the DOM pool prompted the bacterial response. An alternative and not mutually exclusive explanation is that phytoplankton DOM production was simply greater than the rate of DOM use by the bacteria. Additionally, in the second incubation, it appears that degradation of POM may have contributed in part to a continued increase in DOM toward the end of that experiment (Wetz \& Wheeler 2003).

Within approximately $1 \mathrm{~d}$ of nitrate depletion and termination of diatom growth, HNA bacteria reached maximum abundance. Although speculative, it is conceivable that HNA bacterial growth was stopped due to nitrogen limitation, possibly combined with food web interactions. Using an average $\mathrm{N}$ content of $5.8 \mathrm{fg} \mathrm{N} \mathrm{cell}^{-1}$ measured from in situ coastal bacteria (Fukuda et al. 1998), biomass of HNA bacteria at maximum abundance in the first 3 incubations would have ranged from 1.52 to $5.10 \mu \mathrm{mol} \mathrm{l}^{-1} \mathrm{~N}$ (mean $=3.84$ \pm 1.67 ). Reported ammonium regeneration rates in surface water of coastal upwelling systems during the upwelling season generally average $\leq 1.0 \mu \mathrm{mol} \mathrm{l}^{-1} \mathrm{~d}^{-1}$ (Probyn 1987, Neuer \& Franks
Table 1. Mean $( \pm \mathrm{SD})$ net growth rates $\left(\mu, \mathrm{d}^{-1}\right)$ of high nucleic acid (HNA) and low nucleic acid (LNA) bacteria before and after nitrate limitation of phytoplankton blooms. Growth rates were calculated assuming exponential growth. Note that $\mu$ for low DNA bacteria from Days 0 to 5 in Incubation 3 has no SD as only 1 replicate was available

\begin{tabular}{|lcc|}
\hline Days & HNA & LNA \\
\hline Incubation 1 & & \\
$0-3$ & $0.33 \pm 0.02$ & $0.20 \pm 0.04$ \\
$3-5$ & $1.11 \pm 0.07$ & $0.46 \pm 0.05$ \\
Incubation 2 & & \\
$0-4$ & $0.20 \pm 0.06$ & $0.08 \pm 0.04$ \\
$4-6$ & $0.38 \pm 0.15$ & negative \\
Incubation 3 & & \\
$0-5$ & $0.19 \pm 0.00$ & 0.11 \\
$5-7$ & $1.11 \pm 0.13$ & $0.06 \pm 0.09$ \\
Incubation 4 & & \\
$0-5$ & $0.21 \pm 0.01$ & $0.08 \pm 0.02$ \\
$5-7$ & $0.69 \pm 0.06$ & $0.05 \pm 0.00$ \\
& & \\
\hline
\end{tabular}

Table 2. Mean $( \pm \mathrm{SD})$ abundances $\left(\right.$ cells $\left.\mathrm{ml}^{-1}\right)$ of heterotrophic nanoflagellates in deck incubations

\begin{tabular}{|lc|}
\hline Days & Abundance \\
\hline Incubation 1 & \\
0 & $110 \pm 30$ \\
3 & $270 \pm 100$ \\
6 & $3320 \pm 970$ \\
Incubation 2 & $280 \pm 100$ \\
0 & $1460 \pm 180$ \\
3 & $4030 \pm 570$ \\
6 & \\
Incubation 3 & $460 \pm 60$ \\
0 & $3310 \pm 40$ \\
5 & $13340 \pm 1360$ \\
8 & \\
Incubation 4 & $180 \pm 10$ \\
0 & $1170 \pm 60$ \\
5 & $2970 \pm 500$ \\
7 & \\
\hline
\end{tabular}


1993, Dickson \& Wheeler 1995). Considering that secondary phytoplankton blooms, consisting of Synechococcus sp. and small flagellates, developed in the first 3 incubations (M. S. Wetz unpubl. data), it is highly unlikely that the HNA bacteria could have maintained elevated abundances using regenerated ammonium alone. Furthermore, the DON that accumulated following nitrate depletion in the first and third incubations was mostly drawn down (80 and 92\% removed respectively), and the DON that accumulated late in the incubations was either derived from PON degradation (Incubation 2) or from another unknown source (Incubation 1). Thus, we do not know for certain whether that additional DON would be bioavailable to the bacteria over a short time $(<1 \mathrm{~d})$.

After growth of the HNA bacteria had ceased, their abundances decreased rapidly in 3 of the 4 incubations until conclusion of the incubations. Although N limitation may have contributed to the cessation of growth, it is unlikely that it caused the decline in HNA abundance. No increase was observed in LNA abundance as the HNA bacteria decreased, which would be expected if the cells were to go from an active metabolic state to a less active one. This suggests that bacterivory or viral lysing is likely to have caused HNA cell death. The large increases in heterotrophic flagellate abundances, particularly following nitrate depletion of the diatom blooms, strongly suggests that bacterivory played a major role in the decline in HNA bacterial abundances. In the mesocosm study of Painting et al. (1989), a similar rapid (ca. 3 to 5 d) increase in heterotrophic flagellate biomass occurred in relation to bacterial biomass increases that were stimulated by phytoplankton blooms. However, the direct role of flagellate grazing on bacterial biomass and production was not assessed in our study and we are not aware of any studies that have done so in situ off Oregon. Studies in other systems have demonstrated that phagotrophic flagellates often show preferences for larger, actively dividing cells (i.e. HNA bacteria) over dead or dormant cells (Sherr et al. 1992, del Giorgio et al. 1996, Lebaron et al. 1999, Vaqué et al. 2001), which would be consistent with the patterns in bacterial and flagellate abundances observed in this study. Viral lysis is also known to be a major source of mortality for coastal bacteria (e.g. Fuhrman \& Noble 1995, Riemann et al. 2000), but its impact has also not been assessed in this system.

\section{Ecological implications}

It is inherently difficult to extrapolate the results of laboratory studies to field situations. However, as in our case, where we were interested in observing organic matter production by coastal phytoplankton, the incubations proved to be advantageous. The physical dynamics of the Oregon upwelling system make studying in situ blooms from initiation to decay difficult. Advection and vertical mixing leave Langrangian drogue studies subject to uncertain interpretation, and those types of studies would additionally require spending more time at sea, with no guarantee of observing a bloom. Our studies allowed us to repeatedly examine organic matter production and the subsequent bacterial response throughout the entire course of diatom blooms.

Experiments conducted using incubated water can potentially induce unnatural changes in bacterioplankton activity and community composition (e.g. Ferguson et al. 1984, Sherr et al. 1999ba). Two common problems associated with incubation experiments include use of small volume (< a few liters) enclosures which could promote bacterial growth on container walls, and also size fractionation which could uncouple bacteria from natural grazer communities and potentially release DOM through filtration activity. Our experiments were conducted using whole water, so we avoided problems associated with filtration. It is more difficult to assess whether bacterial growth on the container walls was a problem, although we did use fairly large containers $(20$ l) that were vigorously acidwashed beforehand. Furthermore, the changes in bacterial abundance in relation to the development of the diatom blooms are similar to changes observed in other mesocosm experiments (e.g. Painting et al. 1989, Riemann et al. 2000) and in situ (McManus \& Peterson 1988).

Mesocosm studies in other systems have shown accumulation of similar concentrations of DOC and DON following nutrient limitation of diatom blooms (Goldman et al. 1992, Norrman et al. 1995, Smith et al. 1998, Sondergaard et al. 2000). However, Hill (1999) observed an accumulation of DOC that was roughly $100 \mu \mathrm{mol} \mathrm{l}^{-1}$ above deep-water values, while we observed DOC concentrations that were ca. 100 to $250 \mu \mathrm{mol} \mathrm{l^{-1 }}$ more than deep-water concentrations. Thus it is likely that the DOC accumulation in our incubations could have been enhanced due to containment of POC, which would potentially sink out of the euphotic zone in situ. This could account for some of the discrepancy between the incubation and field observations. Furthermore, because the bulk of the DOM that accumulated in our experiments $(\mathrm{C}: \mathrm{N} \geq 16)$ was probably semi-labile, our experiments probably did not last long enough for noticeable bacterial breakdown of the material to occur. This could also account for some of the discrepancy between our estimates of accumulated DOC and those observed in situ. However, given the duration of upwelling events (i.e. 7 to 
$10 \mathrm{~d})$, it is questionable as to how much DOC would degrade in situ before being mixed out of the euphotic zone. For example, McManus \& Peterson (1988) found that in the Chilean upwelling system, maximum bacterial production occurred in stratified surface waters following upwelling, and breakdown of stratification resulting from wind reversal (i.e. to downwelling favorable) resulted in much lower rates of bacterial production.

\section{CONCLUSIONS}

Large amounts of carbon-rich $(\mathrm{C}: \mathrm{N} \geq 16) \mathrm{DOM}$ accumulated following nitrate depletion of upwelling diatom blooms in deck incubations conducted off Oregon. Abundances and growth rates of HNA bacteria increased rapidly concomitant with the DOM build-up, while little response was observed from LNA bacteria. Although net growth rates and abundances of HNA bacteria increased markedly, a net decrease in DOC was only observed in 1 incubation. Immediately after reaching maximum abundance, HNA bacterial abundance decreased. It appears that although $\mathrm{N}$ limitation possibly resulted in cessation of HNA bacterial growth, bacterivory by heterotrophic flagellates or viral lysing are likely to have contributed to the decline. Overall, the results of our study indicate that on the timescale of upwelling events, environmental controls on bacterial populations (i.e. N-limitation, grazing, and possibly viral lysis) may prevent degradation of phytoplanktonderived DOM off Oregon, thus allowing some of the material to be exported from the system through physical processes following termination of upwelling events.

Acknowledgements. We would like to thank E. B. and B. F. Sherr for their constructive comments. Special thanks to B. F. and E. B. Sherr and K. Longnecker for their time and effort in training M.S.W. in flow cytometric analysis. This research was supported by a NASA Space Grant graduate research fellowship to M.S.W. and NSF grants OCE-9907854 and OCE0000733 to P.A.W.

\section{LITERATURE CITED}

Álvarez-Salgado XA, Gago J, Míguez BM, Pérez FF (2001) Net ecosystem production of dissolved organic carbon in a coastal upwelling system: the Ría de Vigo, Iberian margin of the North Atlantic. Limnol Oceanogr 46:135-147

Bevington PR (1969) Data reduction and error analysis for the physical sciences. McGraw-Hill, New York

Bjørnsen PK (1988) Phytoplankton exudation of organic matter: why do healthy cells do it? Limnol Oceanogr 33:151-154

Carlson CA (2002) Production and removal processes. In: Hansell DA, Carlson CA (eds) Biogeochemistry of marine dissolved organic matter. Academic Press, Amsterdam, p 91-151
Carlson CA, Ducklow HW, Michaels AF (1994) Annual flux of dissolved organic carbon from the euphotic zone in the northwestern Sargasso Sea. Nature 371:405-408

Chen W, Wangersky PJ (1996) Rates of microbial degradation of dissolved organic carbon from phytoplankton cultures. J Plankton Res 18:1521-1533

Corwith HL, Wheeler PA (2002) El Niño related variations in nutrient and chlorophyll distributions off Oregon. Prog Oceanogr 54:361-380

del Giorgio PA, Cole JJ (2000) Bacterial energetics and growth efficiency. In: Kirchman DL (ed) Microbial ecology of the oceans. Wiley-Liss, New York, p 289-325

del Giorgio PA, Gasol JM, Vaqué D, Mura P, Agustí S, Duarte CM (1996) Bacterioplankton community structure: protists control net production and the proportion of active bacteria in a coastal marine community. Limnol Oceanogr 41:1169-1179

Dickson ML, Wheeler PA (1995) Ammonium uptake and regeneration rates in a coastal upwelling regime. Mar Ecol Prog Ser 121:239-248

Ducklow H (2000) Bacterial production and biomass in the oceans. In: Kirchman DL (ed) Microbial ecology of the oceans. Wiley-Liss, New York, p 85-120

Eppley RW, Peterson BJ (1979) Particulate organic matter flux and planktonic new production in the deep ocean. Nature 282:677-680

Ferguson RL, Buckley EN, Palumbo AV (1984) Response of marine bacterioplankton to differential filtration and confinement. Appl Environ Microbiol 47:49-55

Fuhrman JA, Noble RT (1995) Viruses and protists cause similar bacterial mortality in coastal seawater. Limnol Oceanogr 40:1236-1242

Fukuda R, Ogawa H, Nagata T, Koike I (1998) Direct determination of carbon and nitrogen contents of natural bacterial assemblages in marine environments. Appl Environ Microbiol 64:3352-3358

Gasol JM, del Giorgio PA (2000) Using flow cytometry for counting natural planktonic bacteria and understanding the structure of planktonic bacterial communities. Sci Mar 64:197-224

Gasol JM, Zweifel UL, Peters F, Fuhrman JA, Hagström Å (1999) Significance of size and nucleic acid content heterogeneity as measured by flow cytometry in natural planktonic bacteria. Appl Environ Microbiol 65: 4475-4483

Goldman JC, Hansell DA, Dennett MR (1992) Chemical characterization of three large oceanic diatoms: potential impact on water column chemistry. Mar Ecol Prog Ser 88: $257-270$

Gordon LI, Jennings JC Jr, Ross AA, Krest JM (1995) A suggested protocol for continuous flow automated analysis of seawater nutrients (phosphate, nitrate, nitrite, and silicic acid) in the WOCE hydrographic program and the joint global ocean fluxes study. Technical Report 93-1, Oregon State University, Corvallis

Hales B, Takahashi T (2002) The pumping SeaSoar: a highresolution seawater sampling platform. J Atmos Ocean Technol 19:1096-1104

Hill JK (1999) The distribution and partitioning of dissolved organic matter off the Oregon coast: a first look. MS thesis, Oregon State University, Corvallis

Hill JK, Wheeler PA (2002) Organic carbon and nitrogen in the northern California current system: comparison of offshore, river plume, and coastally upwelled water. Prog Oceanogr 53:369-387

Lebaron P, Servais P, Troussellier M, Courties C and 6 others (1999) Changes in bacterial community structure in sea- 
water mesocosms differing in their nutrient status. Aquat Microb Ecol 19:255-267

Lebaron P, Servais P, Agogué H, Courties C, Joux F (2001) Does the high nucleic acid content of individual bacterial cells allow us to discriminate between active cells and inactive cells in aquatic systems? Appl Environ Microbiol 67:1775-1782

Li WKW, Jellett JF, Dickie PM (1995) DNA distributions in planktonic bacteria stained with TOTO or TO-PRO. Limnol Oceanogr 40:1485-1495

Libby PS, Wheeler PA (1997) Particulate and dissolved organic nitrogen in the central and eastern equatorial Pacific. Deep-Sea Res 44:345-361

Marie D, Partensky F, Jacquet S, Vaulot D (1997) Enumeration and cell cycle analysis of natural populations of marine picoplankton by flow cytometry using the nucleic acid stain SYBR Green I. Appl Environ Microbiol 63: 186-193

McManus GB, Peterson WT (1988) Bacterioplankton production in the nearshore zone during upwelling off central Chile. Mar Ecol Prog Ser 43:11-17

Neuer S, Franks PJS (1993) Determination of ammonium uptake and regeneration rates using the seawater dilution method. Mar Biol 116:497-505

Norrman B, Zweifel UL, Hopkinson CS Jr, Fry B (1995) Production and utilization of dissolved organic carbon during an experimental diatom bloom. Limnol Oceanogr 40: 898-907

Painting SJ, Lucas MI, Muir DG (1989) Fluctuations in heterotrophic bacterial community structure, activity and production in response to development and decay of phytoplankton in a microcosm. Mar Ecol Prog Ser 53:129-141

Passow U (2000) Formation of transparent exopolymer particles, TEP, from dissolved precursor material. Mar Ecol Prog Ser 192:1-11

Peltzer ET, Hayward NA (1996) Spatial and temporal variability of total organic carbon along $140^{\circ} \mathrm{W}$ in the equatorial Pacific Ocean in 1992. Deep-Sea Res II 43:1155-1180

Probyn TA (1987) Ammonium regeneration by microplankton in an upwelling environment. Mar Ecol Prog Ser 37:53-64

Riemann L, Steward GF, Azam F (2000) Dynamics of bacterial community composition and activity during a mesocosm diatom bloom. Appl Environ Microbiol 66:578-587

Servais P, Casamayor EO, Courties C, Catala P, Parthuisot N, Lebaron P (2003) Activity and diversity of bacterial cells with high and low nucleic acid content. Aquat Microb Ecol

Editorial responsibility: Fereidoun Rassoulzadegan (Contributing Editor), Villefranche-sur-Mer, France
33:41-51

Sherr BF, Sherr EB, McDaniel J (1992) Effect of protistan grazing on the frequency of dividing cells in bacterioplankton assemblages. Appl Environ Microbiol 58: 2381-2385

Sherr BF, del Giorgio PA, Sherr EB (1999a) Estimating abundance and single-cell characteristics of actively respiring bacteria via the redox dye, CTC. Aquat Microb Ecol 18: $117-131$

Sherr EB, Sherr BF, Sigmon CT (1999b) Activity of marine bacteria under incubated and in situ conditions. Aquat Microb Ecol 20:213-223

Sherr EB, Sherr BF, Cowles TJ (2001) Mesoscale variability in bacterial activity in the Northeast Pacific Ocean off Oregon, USA. Aquat Microb Ecol 25:21-30

Smith RL (1995) The physical processes of coastal ocean upwelling systems. In: Summerhayes $\mathrm{CP}$, Emeis $\mathrm{KC}$, Angel MV, Smith RL, Zeitzschel B (eds) Upwelling in the ocean: modern processes and ancient records. John Wiley \& Sons, New York, p 39-64

Smith WO Jr, Carlson CA, Ducklow HW, Hansell DA (1998) Growth dynamics of Phaeocystis antarctica-dominated plankton assemblages from the Ross Sea. Mar Ecol Prog Ser 168:229-244

Sondergaard M, Williams PJL, Cauwet G, Riemann B and 4 others (2000) Net accumulation and flux of dissolved organic carbon and dissolved organic nitrogen in marine plankton communities. Limnol Oceanogr 45:1097-1111

Strom SL, Benner R, Ziegler S, Dagg MJ (1997) Planktonic grazers are a potentially important source of marine dissolved organic carbon. Limnol Oceanogr 42:1364-1374

Vaqué D, Casamayor EO, Gasol JM (2001) Dynamics of whole community bacterial production and grazing losses in seawater incubations as related to the changes in the proportions of bacteria with different DNA content. Aquat Microb Ecol 25:163-177

Wetz MS, Wheeler PA (2003) Production and partitioning of organic matter during simulated phytoplankton blooms. Limnol Oceanogr 48:1808-1817

Zubkov MV, Fuchs BM, Burkill PH, Amann R (2001) Comparison of cellular and biomass specific activities of dominant bacterioplankton groups in stratified waters of the Celtic Sea. Appl Environ Microbiol 67:5210-5218

Zweifel UL, Hagström $\AA$ (1995) Total counts of marine bacteria include a large fraction of non-nucleoid-containing bacteria (ghosts). Appl Environ Microbiol 61:2180-2185

Submitted: September 16, 2003; Accepted: January 26, 2004 Proofs received from author(s): May 13, 2004 